\title{
Adapting to climate change in the fishery industry case study: Phuoc Hai and Phuoc Tinh fishing villages of Ba Ria - Vung Tau province, Vietnam
}

\author{
Tran Thi Doan Trinh, Le Hai Nguyen
}

\begin{abstract}
Ba Ria - Vung Tau Province is part of the South Eastern key economic zone. This province is the gate to the Southeast Asia Sea of the South Eastern region. Ba Ria - Vung Tau has a coastal line of 350 kilometers and the estimated area of the continental shelf of $\mathbf{1 0 0 , 0 0 0}$ square kilometers. These geographical conditions have helped developed fishery and seafood processing industry. In the late ten years, many changes in climate and weather condition has had strong impact on the local life of those who live in the coastal area and mostly live on fishery. In order to adapt with those changes, people have actively seeked and opted for different measures which are applicable for their socioeconomic condition. Using descriptive statistics to analyze both primary and secondary data of two study areas, this paper discuss some solutions the communities have used to adapt to climate change. Then the authors propose some recommendations to assist the people in selecting solutions for climate change adaptation.
\end{abstract}

Keywords - fishery industry, climate change, adaptation

\section{INTRODUCTION}

A ccording to World Bank [1], Vietnam has been warned to be one of the five countries in the world which is most affected by climate change. Coastal lowlands in southern Vietnam are considered more vulnerable to climate change because of their relatively high concentration of densely populated areas. Furthermore, agricultural

Received: 10-11-2017, Accepted: 21-12-2017; Published: 30-6-2018

Tran Thi Doan Trinh, Le Hai Nguyen Department of Geography, University of Social Sciences and Humanities, Ho Chi Minh City

Email: trinh.trandoan@gmail.com,

Email: hainguyen.le@gmail.com and fishery production in those regions are heavily dependent on the weather and water source. Ba Ria - Vung Tau is a coastal province in the Southeast of Vietnam. The long coastline has become the advantage that facilitates the province to develop tourism, fishing and other marine economic sectors. However, this geographic condition also makes Ba Ria - Vung Tau, especially the coastal communities and marine dependent occupations, a vulnerable place to climate change impacts. The data from the Institute of Meteorology and Hydrology in the South showed that the province has been experiencing different climate change effects such as average temperature rising, precitipation decreasing, rapid coastal erosion, and fresh water shortage [2, 3]. In order to deal with those impacts, the people have imposed different responses to lessen the consequences. This paper discusses some solutions the communities have used to adapt to climate change. Then the authors propose some recommendations to assist the people in selecting solutions for climate change adaptation.

\section{LITERATURE REVIEW}

In order to response to the impacts of climate change, society often focuses on two main options, mitigation and adaptation [4]. On the scale of households, in fishery industry, people can only choose to adapt to climate change due to their limited resources. Adaptation is defined by the Intergovernmental Panel on Climate Change (IPCC) as "Initiatives and measures to reduce the vulnerability of natural and human systems against actual or expected climate change effects" [4]. Wongbusarakum and Loper [5] argued that successful adaptation strategies would reduce vulnerability by increasing adaptive capacity and 
decreasing exposure and sensitivity. There are various ways to categorize adaptation depend on different concerned actors. One common classification divides adaptation into two types, autonomous and planned adaptation [6, 7]. Autonomous adaptation tends to be more responsive to the already happened effects of climate change such as changing fishing location.
Planned adaptation, on the other hand, is responsive to potential risks from climate change. Planned adaptation often results in investing more to secure future living [7, 8]. Besides those adaptation strategies, coping is considered to be a short-term survival mechanism $[8,9]$. Figure $1[8]$ shows the required time scale and the amount of benefits and costs that various types of adaptation.

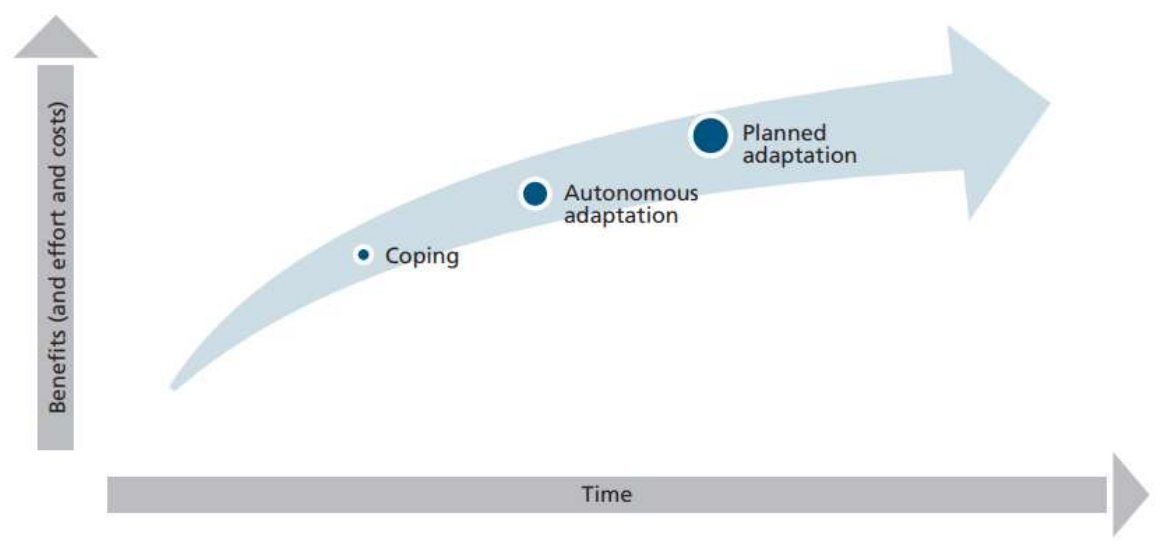

Figure1. Time scale and amount of benefits and costs required for various types of adaptation

\section{METHODOLOGIES}

\subsection{Data collecting and analyzing}

Secondary data consist of statistical reports about socio-economic activities and weather data. The statistical reports about socio-economic activities of the two study areas are available from the People's Committee of Ba Ria - Vung Tau. The weather data was achieved from the Institute of Meteorology and Hydrology in the South.

Primary data were collected by using questionnaires, in-depth interviews, and group discussions. In-depth interviews aimed at exploiting the following information from the community: household options for solving employment problems when there is climate change; impacts of climate change on economic activity, working time, income and expenses in the family; and experience in dealing with climate change of the household. For local authorities, this tool aims to exploit information on: adaptation measures for local government (short-term and long-term) adaptation; advantages and disadvantages in the implementation of solutions; and expectations and suggestions to maintain the solution.
Two group discussions were conducted in two study areas to determine which impact of climate change was the most profound one on the community's economic activities, and social and spiritual life. The discussions also helped to identify what types of solutions were accepted by the community and applied the most lately.

The survey was conducted with 110 households which were divided into two areas: 55 households in Phuoc Hai fishing village and the other of 55 in Phuoc Tinh fishing village. Random sampling method was used to select households. Data were analyzed using descriptive statistics. Then, comparisons were also made between study areas.

\subsection{Study areas}

Phuoc Hai fishing village is located in Phuoc Hai town, Dat Do district, Ba Ria - Vung Tau province. Phuoc Hai town is located in the south of Dat Do district. It has a natural area of 1,566.97 hectares with a 7.8 kilometers long coastline, and a population of over 24,000 people which is distributed along the coast and downtown. The main livelihood of the people is harvesting seafood with the total of 690 large and small ships, the estimating annual fish harvest of $35-40$ thousand tons, of which $35-40 \%$ is used for export [10]. 
Among the fishing villages in Ba Ria - Vung Tau, Phuoc Hai is the one that has the oldest history. It was since the $18^{\text {th }}$ century when the people started their fishery career and became wealthier as time went by. Over the generations, Phuoc Hai fishery is regarded as a traditional profession, successive from generation to generation. Nearly $80 \%$ of the population here is living on fishing and processing of seafood, while the rest of the population is mainly engaged in farming and trading. Therefore, this area is strongly developed for offshore fishing and fishery services.

Phuoc Tinh fishing village in Phuoc Tinh town is a coastal town, located in the southwest of Long Dien district, Ba Ria - Vung Tau province. Phuoc Tinh is a busy fishing village of Long Dien district, Ba Ria Vung Tau province, with more than $80 \%$ of households doing offshore fishing and the rest live on fishery services. As reported by the People's Committee of Phuoc Tinh in 2013 [11], the annual per capita income here is 50 million VND. This is quite high compared to many other localities in the country. Phuoc Tinh has 5 shipbuilding yards, attracting hundreds of skilled workers and lots of local workers. Every year, Phuoc Tinh launches more than forty offshore fishing boats. Besides being able to build new vessels, Phuoc Tinh is also a very prestigious place in repairing and overhauling of ships.

The majority of respondents in the study area were between 41 and 60 years of age, accounting for 61.8 percent. There is no big difference about the ratio of males and females in two study areas. The majority of respondents have received an elementary education (69-72.7\%).

Table 1

Main income-earning profession of the family

\begin{tabular}{|l|l|l|l|l|l|l|}
\hline \multirow{2}{*}{ Professions } & \multicolumn{2}{|l|}{ Phước Hải } & \multicolumn{2}{l|}{ Phước Tỉnh } & \multicolumn{2}{l|}{ Total } \\
\cline { 2 - 7 } & $\begin{array}{l}\text { Number of } \\
\text { samples }\end{array}$ & $\%$ & $\begin{array}{l}\text { Number of } \\
\text { samples }\end{array}$ & $\%$ & $\begin{array}{l}\text { Number of } \\
\text { samples }\end{array}$ & $\%$ \\
\hline Offshore fishing & 26 & 47.3 & 35 & 63.7 & 61 & 55.5 \\
\hline Nearshore fishing & 13 & 23.6 & 13 & 23.6 & 26 & 23.7 \\
\hline Workers in fisheries & 9 & 16.4 & 6 & 10.9 & 15 & 13.6 \\
\hline Trading & 4 & 7.3 & 0 & 0.0 & 4 & 3.6 \\
\hline Others & 3 & 5.4 & 1 & 1.8 & 4 & 3.6 \\
\hline Total & 55 & 100.0 & 55 & 100.0 & 110 & 100.0 \\
\hline
\end{tabular}

As shown in table 1 above, in both locations, the main profession is offshore fishing $(47.3 \%$ and $63.7 \%$, respectively which is often responsible by the male in the household. The second highest percentage of job type is nearshore fishing (23.7\% of total). Fishing has become a tradition, a hereditary profession in these 2 villages. Households from nearshore fishing with rudimentary equipment, over the years have been able to build boats for offshore fishing. Accompanied with them are boat workers, comprised of $13.6 \%$ of the total, who receive compensation according to the percentage of product value.

\section{ADAPTATION SOLUTIONS TO CLIMATE CHANGE OF THE FISHERIES COMMUNITY}

As climate change is gradually becoming a matter of concern not only at the global or national level, but also as a policy of action in each locality, local communities started to pay attention to climate change. For rural fishery communities living in Ba Ria - Vung Tau coastal province, where the impacts of climate change are no longer a vague concept and become more apparent, people have been actively choosing and looking for measures suited to the socio-economic conditions of themselves and their families in order to adapt to these changes in climate condition.

The study area, which is two famous fishing villages, has a long tradition in many different services related to fisheries and fishing activities. When there are threats caused by nature that can directly affect seamanship, people have to consider and choose the most suitable solutions that can utilize their current resources such as 
capital and labor resources while adapting to the abnormal climatic fluctuations. The solutions of the local community to this issue in either shortterm or long-term are to adapt to weather changes. Once practical solutions have been implemented, the people themselves will feel more secure in working and living. The long-term goal of the local residents is that when they are well prepared with the support and guidance from local and regional authorities, they will not suffer as much damage as they did in the past if disasters occur. In their mind, they do not want to evade extreme disasters in a radical way, instead, they want to continue their life and work. Their solutions focused on two aspects including economic activities, which were career realted options and social life, which relates to resettling issues.

\subsection{Solutions to the economic problems}

The local people choose two solutions to the economic problems of the family in the context of climate change: (1) changing career; or (2) not changing career, maintaining and expanding the scale of the fishery.

Through the survey of people who work in fishery in two fishing villages, we collected the following information shown in table 2:

Table 2

Prefered career shifting solutions

\begin{tabular}{|l|l|l|l|l|l|l|}
\hline \multirow{2}{*}{ Solutions } & \multicolumn{2}{l|}{ Phước Hải } & \multicolumn{2}{l|}{ Phước Tỉnh } & \multicolumn{2}{l|}{ Total } \\
\cline { 2 - 7 } & $\begin{array}{l}\text { Number of } \\
\text { response }\end{array}$ & $\%$ & $\begin{array}{l}\text { Number of } \\
\text { response }\end{array}$ & $\%$ & $\begin{array}{l}\text { Number of } \\
\text { response }\end{array}$ & $\%$ \\
\hline a. Changing fishing career & & & & & & \\
\hline From offshore fishing to nearshore fishing & 6 & 10.9 & 2 & 3.6 & 8 & 7.3 \\
\hline From catching to aquaculture & 0 & 0.0 & 1 & 1.8 & 1 & 0.9 \\
\hline From catching to cultivating & 0 & 0.0 & 2 & 3.6 & 2 & 1.8 \\
\hline From catching to breeding & 0 & 0.0 & 1 & 1.8 & 1 & 0.9 \\
\hline From nearshore fishing to offshore fishing & 3 & 5.5 & 2 & 3.6 & 5 & 4.5 \\
\hline Trading & 7 & 12.7 & 6 & 10.9 & 13 & 11.8 \\
\hline b. Do not change profession & 39 & 70.9 & 41 & 74.5 & 80 & 72.7 \\
\hline Total & $\mathbf{5 5}$ & $\mathbf{1 0 0 . 0}$ & $\mathbf{5 5}$ & $\mathbf{1 0 0 . 0}$ & $\mathbf{1 1 0}$ & $\mathbf{1 0 0 . 0}$ \\
\hline
\end{tabular}

(1) Changing career solution.

Among the households that intend to switch careers, $11.8 \%$ of the total respondents plan to change to trading. According to them, this job is safer and does not require strong labors compare to offshore fishing. Furthermore, it is more suitable for women, who wish to work to share the family burden with the men. Most of them opt to become small traders, who need capital and a proper trading place. Those who intend to switch to trading expressed their desire to resettle in a new place for their new jobs. Another occupational shift is that of households from nearshore fishing to offshore fishing $(4.5 \%$ of total) and offshore fishing for nearshore fishing (7.3\% of total). For households changing to offshore fishing, according to the respondents' explanations, they believe that this change is not due to natural disasters, but rather the need for their family development. These households have a stable source of funding, high manpower and long-term goals. On the contrary, the decision of households switching to nearshore fishing is influenced by climate change. Those who have been fishing offshore are employed by boat owners and have a lot of experience in sea travel and in facing natural disasters. After witnessing the devastation of large storms in their living area, they and their families started to worry about the safety of their work. They explained that when changing from offshore to nearshore fishing, although their income will decrease, in return, their family and they will feel at ease expecting the typhoon season. Additionallly, they also have more time to care for the family and help the family overcome the ravages of the storms. Besides, they thought that they can settle down quickly with the new living condition. "Not going 
to the sea means earning less money, spending needs more consideration, my family also has to work more. I am now older after going to the sea for so many years. I fear that I cannot stand the big waves like before" (Male, 56 years old, Phước Hải).

Job changing is an important decision regarding the long-term livelihood of the people. Most households that follow a long-term process will completely abandon their old professions. Additionally, in recent years, tourism activities are becoming more popular in these two fishing villages, which means that people's jobs are expanded. Some households participate in tourism activities such as operating homestay services, hostels, restaurants and other related jobs in tourism industry.

(2) Not changing career solution, instead maintaining and expanding the scale of the fishery with the goal of ensuring the safety of human life and property in the event of a disaster.

On the contrary, middle-aged and older people are trying to maintain the fishing profession. For them, offshore fishing is not only earning the living but also protecting of the traditional fishing grounds of this country. "(I) ... want to change the job but in Phuoc Tinh, (I) ... do not know what to do besides fishing. Fishing is a job, a debt (that I) owed to my ancestors. Smelling the sea, I want to go offshore again" (Male, 50 years old, Phước Tỉnh).

Among the households who did not choose to change their occupation, most of them advocated the expansion of the family's occupation. They invested more money in the fleet of boats, built new ships with high capacity, purchased fishing gears and other necessities for offshore fishing in a long period of time such as walkie-talkies and satellite telephones to communicate with the land when disasters occur. They also stated that nearshore resources are depleted due to many reasons including over-exploitation and ineffective management of marine resources, etc. Marine resources exhaustion is causing many households fishing nearshore to abandon their job. Moreover, in recent years, weather conditions fluctuate erratically making life more difficult. In order to stick to fisheries, they need to invest in facilities and change their fishing methods. The shift to offshore fishing helps to expand the fishing area and therefore improves the likelihood of fish catching.
However, there is a difficulty in implementing this solution. It is the lack of capital to equip and upgrade fishing vessels and means of communication in order to maintain the connection between the people at sea and inland, especially during the time the disasters occur. In addition, the shortage of sea workers in the local area also risks reducing the scope of the fishery significantly. According to the local people, young generation who have proper education did not want to continue their father's career in fisheries. They have different career plans and dreams in big cities with more stable and less dangerous jobs.

\subsection{Solutions to resettlement and the long-term stability}

Together with the solutions to the problem of economic activities of the family to adapt to weather changes, the interviewed households expressed their concerns about the resettlement and the long-term stability in the fishing villages. There are two groups of solutions chosen by the households in the study area, including (1) building new construction or repairing and reinforcing the house depend on their economic ability; and (2) relocating to a safer place.

(1) Building new construction or repairing and reinforcing the house depend on the economic ability of household.

After suffering many disasters over the years, coastal communities have increased their awareness of natural disasters and unusual changes of the weather. Carelessness in dealing with disasters no longer exists. People themselves and their families are more active in preventing natural disasters in the locality. One of the solutions is repairing and reinforcing houses since most of the households are living along the coast in level 4 houses and in temporary houses. These type of houses do not ensure the safety of the family members as well as their fortune when extreme natural phenomena, especially heavy storms, occur. Depending on their own economic resources, each household have varied short-term and long-term solutions to home improvement options as shown in table 3 . The solutions to build new houses together with the construction of shelters are long-term options of the family, this option accounts for a ratio of 45.5 percent in Phuoc Hai and 37.5 percent in Phuoc Tinh. Meanwhile, people give priority to minor repairs in Phuoc Hai (54.5\%) and in Phuoc Tinh (62.5\%). 
Table 3

House repairing solutions

\begin{tabular}{|l|l|l|l|l|l|l|}
\hline \multirow{2}{*}{ Solutions } & \multicolumn{2}{l|}{ Phước Hải } & \multicolumn{2}{l|}{ Phước Tỉnh } & \multicolumn{2}{l|}{ Total } \\
\cline { 2 - 8 } & $\begin{array}{l}\text { Number of } \\
\text { response }\end{array}$ & $\%$ & $\begin{array}{l}\text { Number of } \\
\text { response }\end{array}$ & $\%$ & $\begin{array}{l}\text { Number of } \\
\text { response }\end{array}$ & $\%$ \\
\hline Build new construction & 15 & 19.5 & 10 & 17.9 & 25 & 18.8 \\
\hline Build a permanent shelter & 20 & 26.0 & 11 & 19.6 & 31 & 23.3 \\
\hline Reinforce the roof & 31 & 40.2 & 25 & 44.6 & 56 & 42.1 \\
\hline Reinforce columns, trusses, and walls & 11 & 14.3 & 10 & 17.9 & 21 & 15.8 \\
\hline Total & 77 & 100.0 & 56 & 100.0 & 133 & 100.0 \\
\hline
\end{tabular}

Households who do not have financial resource tend to choose small repairs such as reinforcing roofs by using heavy sandbags or reinforcing trusses and walls to withstand strong winds. For better-off households, they built solid shelters following the local government's recommendation. This type of shelter is usually built near the main house, which is convenient for avoiding natural disasters. It is often constructed with strong walls and ceiling that can withstand strong winds. For households who are determined not to leave their homes despite of natural disasters, this is a proper choice, since they do not have to relocate their property and still are able to look after their houses.

(2) Relocating to a safer place

Table 4

House relocation solutions

\begin{tabular}{|c|c|c|c|c|c|c|}
\hline \multirow[b]{2}{*}{ Solutions } & \multicolumn{2}{|l|}{ Phước Hải } & \multicolumn{2}{|l|}{ Phước Tỉnh } & \multicolumn{2}{|l|}{ Total } \\
\hline & $\begin{array}{l}\text { Number of } \\
\text { response }\end{array}$ & $\%$ & $\begin{array}{l}\text { Number of } \\
\text { response }\end{array}$ & $\%$ & $\begin{array}{l}\text { Number of } \\
\text { response }\end{array}$ & $\%$ \\
\hline $\begin{array}{l}\text { Move into another area near the old } \\
\text { place, far from the sea }\end{array}$ & 25 & 71.4 & 20 & 76.9 & 45 & 73.8 \\
\hline Move deep into densely populated areas & 8 & 22.9 & 6 & 23.1 & 14 & 22.9 \\
\hline Transfer to another locality & 2 & 5.7 & 0 & 0.0 & 2 & 3.3 \\
\hline Total & 35 & 100.0 & 26 & 100.0 & 61 & 100.0 \\
\hline
\end{tabular}

Table 4 showed that most households agreed to move to another area far from the sea but still close to the old place, accounting for $73.8 \%$ in both study sites. The main reason is that they can both avoid the direct impact of the storm but still be able to continue their hereditary profession, as well as not have to leave their old home, neighbors and other relationships. Those households who want to change their career, prefer to move into a densely populated area. However, the majority of people say they still stick to the sea and maintain the same place of residence. Stable settlements and occupations are two of the most practical requirements of the people. Although being threatened by natural disasters, local people are not able to immediately make the decision to change their long-term settlements which can cause life disturbances. Furthermore, moving to a new home causes new worries and challenges. Finding a suitable career in a short time is also a big challenge for those people if they do not get the adequate supports from the local authorities.

It is very clear that the community's psychological attachment to the land and the sea in the study area is very strong. They thought that the change of living space was an immediate solution when natural disasters occur. After that, they will return to the old houses, so the solution of relocation, for these people, is a short-term measure. Their attachment to the land, ancestors, and the long-standing traditions of the sea community are still preserved and maintained up to the present. Without any very special reasons, most local people do not want to change their residence. They attached themselves and their families to the land and houses as well as fishery activities for a long time. Therefore, stability and long-term livelihoods for local people need to be 
taken into consideration when developing support programs for them.

\section{SOME RECOMMENDATIONS TO SUPPORT THE FISHING VILLAGE PEOPLE IN SELECTING SOLUTIONS TO ADAPT TO CLIMATE CHANGE}

The implementation of response measures from the provincial level, local authorities, and people living in the affected areas should be done in a timely manner with different aspects. The suggested solution groups should be divided into 3 phases: (1) short-term solution group; (2) medium-term solution group; and (3) long-term solution group.

Regarding short-term solutions, local authorities should focus on helping the community to cope with natural disasters. This is an urgent action to deal with storms and floods that occur every year. Due to the lack of financial resources, the people have difficulty in reinvesting means of production as well as reinforcing and repairing houses after those events. Preferential credit funding is a feasible option for the people. Offering favorable clauses to the people gives them opportunities to access to these credit sources to reinvest their means of production and repair houses affected by natural disasters. The establishment of emergency reserves and disaster prevention funds will also increase the government's ability to respond to the impact of natural disasters and help stabilize the postdisaster economy caused by the consequences of climate change. In addition to financial resources, the development of human resources is another short-term strategy that can be applied. Effective social security policies will help to mitigate the effects of poverty resulted by the rising of commodity prices. A number of popular programs may be used, including food service programs and job security programs. In the long term, the social safety network will help people feel peace of mind in investing in the future such as investing in education, training, and nutrition. As a result, people will be likely to have more stable jobs and income. Besides, with the new skills and knowledge provided, people have more flexibility in changing jobs and developing new careers when they face difficult conditions.

For medium-term solutions ( 3 - 5 years), the actions to be taken at this stage are to collect information and data (such as information related to sea level rise) to prepare suitable plans of building and developing infrastructure. Good means of communication, traffic, and early warning systems will help evacuate people quickly in the event of a storm. Well-built infrastructure will increase the ability of people to cope with short-term climate shocks and to adapt to climate change in the long run.

Regarding the long-term solutions (20 - 50 years), in this phase, it is necessary to analyze the climate change scenarios presented by the Ministry of Natural Resources and Environment. For example, how the sea level rise of up to 50 centimeters in coastal areas will affect the lives of people. Therefore, in order to prepare for longterm goals, plans for land-use and resettlement for the people should be made from now. In addition to the government-initiated macro planning and policies, propaganda on the protection and management of coastal natural resources also needs to be addressed. Along with the protection, the restoration and improvement of natural environment is also a task that needs more attention. Activities such as mangrove rehabilitation and reforestation will contribute to the increase of natural resources for local communities.

\section{CONCLUSION}

In recent years, due to the effects of climate change, natural disasters around the world have been occurring more frequently with higher complexity and intensity which exacerbates the impact of natural disasters on mankind. In particular, the lowland and coastal areas will be most impacted. In that context, rural communities in coastal Ba Ria - Vung Tau province working in the fishery sector also have certain perceptions about the erratic changes of weather in the area. Since then, they have taken the initiative to choose a variety of solutions, both economically and socially, to adapt to the increasingly severe changes in climate. However, their vulnerablity with climate change is still high due to their lack of resources. Therefore, the local authorities should offer more supporting to the people through programs and plans that are practical, timely and have a long-term vision to enhance self-resilience to climate change and to build sustainable livelihood for fishermen living in the area. 


\section{REFERENCES}

[1]. World Bank, "The economics of adaptation to climate change: A Synthesis Report," World, no. August, p. 84, 2010.

[2]. Trương Thành Công, "Ba Ria - Vung Tau to respond to climate change," The steering committee of the action program adapt to climate change in agriculture and rural development, 2011.

[3]. Phạm Thu Hà, "Ba Ria - Vung Tau: Protection of coastal areas and estuaries in coping with climate change," Department of Meteorology, Hydrology and Climate Change - Ministry of Natural Resources and Environment, 2014.

[4]. IPCC, Climate change 2001: impacts, adaptation, and vulnerability: contribution of Working Group II to the third assessment report of the Intergovernmental Panel on Climate Change. 2001.

[5]. S. Wongbusarakum and C. Loper, "Indicators to assess community-level social vulnerability to climate change: An addendum to SocMon and SEM-Pasifika regional socioeconomic monitoring guidelines," Nat. Conserv. NOAA Coral Reef Conserv. Progr., 2011.

[6]. B. Smit, I. Burton, R. J. T. Klein, and J. Wandel, “An Anatomy of Adaptation to Climate Change and Variability," Climate Change, vol. 45. pp. 223-251, 2000.

[7]. S. Fankhauser, J. B. Smith, and R. S. J. Tol, "Weathering climate change: Some simple rules to guide adaptation decisions," Ecol. Econ., vol. 30, no. 1, pp. 67-78, 1999.

[8]. FAO, The state of world fisheries and aquaculture, vol. 2014. 2014.

[9]. H. M. Füssel, "Adaptation planning for climate change: Concepts, assessment approaches, and key lessons," Sustainability Science, vol. 2, no. 2. pp. 265-275, 2007.

[10]. People's Committee of Phuoc Hai, "On summarizing the economic, socio-cultural, security and defense developments in 2013 and the 2014 orientations," 2013.

[11]. People's Committee of Phuoc Tinh, "On summarizing the economic, socio-cultural, security and defense developments in 2013 and the 2014 orientations," 2013.

\title{
Thích ứng với biến đổi khí hậu trong nghề cá trường hợp điển cứu: làng cá Phước Hải và làng cá Phước Tỉnh, tỉnh Bà Rịa - Vũng Tàu, Việt Nam
}

\author{
Trần Thị Đoan Trinh, Lê Hải Nguyên \\ Trường Đại học Khoa học Xã hội và Nhân văn, ĐHQG-HCM \\ Email liên hệ: trinh.trandoan@gmail.com, hainguyen.le@gmail.com
}

Ngày nhận bản thảo: 10-11-2017; Ngày chấp nhận cho đăng bài: 21-12-2017; Ngày đăng bài: 30-6-2018

Tóm tắt-Bà Rịa - Vũng Tàu (BR - VT) là một tỉnh nằm trong vùng kinh tế trọng điểm Đông Nam Bộ. Tỉnh có đường bờ biển dài $305 \mathrm{~km}$ và có diện tích vùng thềm lục địa khoảng $100,000 \mathrm{~km}^{2}$. Tỉnh BR - VT chính là cửa ngõ hướng ra biển Đông của các tỉnh trong khu vực miền Đông Nam Bộ. Vị trí này cho phép tỉnh $B R$ - VT hội tụ nhiều tiềm năng để phát triển các ngành kinh tế biển như: khai thác dầu khí trên biển, khai thác cảng biển và vận tải biển, khai thác và chế biến hải sản, phát triển $\mathrm{du}$ lịch nghỉ dưỡng và tắm biển. Trong đó, khai thác và chế biến hải sản là một ngành có truyền thống lâu đời tại địa phương. Trong khoảng mười năm gần đây, những thay đổi trong khí hậu và điều kiện thời tiết đã ảnh hưởng lớn đến đời sống của người dân địa phương, những người chủ yếu sống ven biển và dựa vào nghề cá. Nhằm có thể thích ứng với những thay đổi này, người dân đã chủ động và tích cực hơn trong việc lựa chọn, tìm kiếm những biện pháp phù hợp với điều kiện kinh tế - xã hội của bản thân và gia đình. Bài báo sử dụng phương pháp thống kê mô tả để phân tích dữ liệu sơ cấp và thứ cấp thu thập cho cả hai khu vực điển cứu. Tù̀ đó bài báo chỉ ra những đặc điểm của các giải pháp mà cộng đồng địa phương đã sử dụng cho việc thích ứng với biến đổi khí hậu. Dựa vào đó, các tác giả đề xuất những biện pháp hỗ trọ̣ người dân địa phương trong việc lựa chọn những giải pháp này.

Tù khóa-nghề cá, biến đổi khí hậu, thích ứng 